\title{
Evaluation of Pea (Pisum sativumL.) and Indian Mustard (Brassica juncea L.) Intercropping System on Growth, Yield and Competition Indices
}

\author{
Mary Chongtham ${ }^{1}$, K. Nandini Devi ${ }^{1}$ *, Nurina Shahni ${ }^{1}$, Herojit Singh Athokpam ${ }^{1}$, \\ N. Gopimohan Singh ${ }^{1}$, Kangujam Bokado ${ }^{2}$ and A. Dorendro Singh ${ }^{3}$ \\ ${ }^{1}$ College of Agriculture, Central Agricultural University, Imphal - Manipur, India \\ ${ }^{2}$ Assam Agriculture University, Jorhat - Assam, India \\ ${ }^{3}$ Department of Botany, MayaiLambi College, Yumnam Huidrom, Imphal West, India \\ *Corresponding author
}

\begin{abstract}
A B S T R A C T
Keywords

Economics,

Growth, Indices, Indian mustard, Pea, Yield

Article Info

Accepted:

17 June 2018

Available Online:

10 July 2018

A field experiment was carried out using two varieties of pea (Rachna and local cultivar Makhyatmubi) and one Indian mustard (NRCHB 101)intercropping systems to determine the competition among these and economics of each intercropping system. The intercropping systems were assessed on the basis of existing competition and economic indices such as land equivalent ratio (LER), relative crowding coefficient, aggressivity, competitive ratio (CR), relative crowding coefficient (RCC) and monetary advantage index (MAI). Yields of individual crop were higher when grown as sole crops compared with their intercropping. Competition ratio and aggressivity value were higher in the intercropping of Makhyatmubi with Indian mustard in row ratio of $1: 1$. Whereas Makhyatmubi intercropped with Indian mustard in row ratio of 2:1 gave the maximum Makhyatmubi Equivalent Yield (1830 kg/ha), Land Equivalent ratio (1.51), Relative Crowding Coefficient values (8.23) and Monetary Advantage Index (Rs.60883/ha) indicating a definite yield and monetary advantage.
\end{abstract}

\section{Introduction}

Intercropping is a crop management system involving the growing of two or more economic dissimilar crop species or varieties in distinct row combinations simultaneously on the same piece of land. Conceptually, intercropping system helps for risk avoidance from epidemic of insect-pest and disease, and overcome the effect of adverse environmental conditions in agro-climatologically unstable regions along with better utilization of solar radiation and inputs like fertilizer and water compared to crops in sole system. It means intercropping not only reduces the risk factors, but also increases the profit. In intercropping systems, differences may occur between the component crops in competitive ability for growth resources. Yield advantage occurs because growth resources such as light, water and nutrients are more efficiently absorbed and converted to biomass by the component crops over time and space. Normally, complementary use of resources occurs when 
the component crops of an intercropping system use different resources or they use the same resources at different places or at different times. This results due to the variation in characteristics of component crops such as rates of vegetative growth, final canopy size, photosynthetic adaptation of canopies to prevailing light conditions and nature of root system, including rooting depth (Tsubo et al., 2001).

Selection of crops differing in competitive ability in time or space is essential for an efficient intercropping system as well as making decisions on planting time, density and arrangement. Thus, crop management decisions specify the design of intercropping systems, and its performance is governed largely by the availability and the competition for growth resources. It has also been found to be most useful (Adeniyi, 2011) because of its economic advantages resulting from nitrogen fixing activity of legumes intercropped with other crops. Legumes grown in intercropping are regarded as an alternative and sustainable way of introducing nitrogen into lower input agro-ecosystems (Fustecet al., 2010).

Therefore, keeping in view, the present investigation "Pea

(PisumsativumL.)based intercropping system with Indian mustard (Brassica juncea L.) on growth, yield and competition indices" was carried out with the objectives to find out the suitable pea variety for intercropping with Indian mustard, their suitable combination of intercropping and the economics.

\section{Materials and Methods}

The experiment was conducted during rabi season of 2016-17 and repeated in 2017 2018 at the Research Farm of College of Agriculture, Central Agricultural University, Imphal. For the experiment two varieties of pea (Rachna and Makhyatmubi) and one Indian mustard (NRCHB 101) were used. The experiment consist of nine treatment viz., $\mathrm{T}_{\mathbf{1}}$ Sole Rachna; $\mathrm{T}_{\mathbf{2}}$ - Sole Makhyatmubi; $\mathrm{T}_{3}$ Sole Indian mustard; $\mathrm{T}_{\mathbf{4}}$ - Rachna + Indian mustard (1:1); $\mathrm{T}_{\mathbf{5}}$ - Makhyatmubi + Indian mustard (1:1); $\mathrm{T}_{6}-$ Rachna + Indian mustard (2:1); $\mathrm{T}_{7}$ - Makhyatmubi + Indian mustard (2:1); $\mathrm{T}_{\mathbf{8}}$ - Rachna + Indian mustard (3:1); $\mathrm{T}_{\mathbf{9}}$ - Makhyatmubi + Indian mustard (3:1). The experiment was laid out in randomised block design with three replications. The soil of the experimental site is clay. The soil has $\mathrm{pH}$ (5.4), organic carbon (1.2\%), available $\mathrm{N}$ (251.53 kg/ha), $\mathrm{P}_{2} \mathrm{O}_{5}(16.45 \mathrm{~kg} / \mathrm{ha})$ and $\mathrm{K}_{2} \mathrm{O}$ $(218.80 \mathrm{~kg} / \mathrm{ha})$. The crops were raised in rainfed condition. The seeds of pea and Indian mustard were sown in replacement series in all intercropping plots except sole. The seeds of both pea and rapeseed were treated with carbendazim @ 5g/kg seed just before sowing to protect from soil and seed borne diseases. The treated seeds of pea varieties Makhyatmubi, Rachna and Indian mustard variety NRC HB-101 were sown on $27^{\text {th }}$ and $30^{\text {th }}$ November, 2016 and 2017 and harvested on $28^{\text {th }}$ March, 2017 and $1^{\text {st }}$ April, 2018 respectively. Pea variety 'Makhyatmubi' was a susceptible to lodging local cultivar of Manipur. A uniform dose of $\mathrm{N}(20 \mathrm{~kg} / \mathrm{ha})$, $\mathrm{P}_{2} \mathrm{O}_{5}(60 \mathrm{~kg} / \mathrm{ha})$ and $\mathrm{K}_{2} \mathrm{O}(40 \mathrm{~kg} / \mathrm{ha})$ was applied to all the plots as basal. All the other cultural practices were carried out during both the years. Data on growth and yield attributing characters were recorded and analysed statistically. The intercropping systems were assessed on the basis of existing competition and economic indices such as land equivalent ratio (LER), relative crowding coefficient $(K)$, aggressivity $(A)$, competitive ratio (CR), actual yield loss (AYL), intercropping advantage and monetary advantage index (MAI).

\section{Makhyatmubi Equivalent Yield (MEY)}

The Makhyatmubi Equivalent Yield was calculated from the ratio of price unit weight of the concerned crop (Rachna and Indian 
mustard) by the price unit weight of Makhyatmubi (Verma and Modgal, 1983).

$\mathrm{MEY}=\frac{Y X P i}{\mathrm{Pc}}$

Where, $\mathrm{Y}=$ Yield of a crop, which need conversion,

$\mathrm{Pi}=$ Price offered to a crop $\mathrm{Y}$

$\mathrm{Pc}=$ Price offered to crop, in whose terms $\mathrm{Y}$ is being expressed.

\section{Land Equivalent Ratio (LER)}

Proposed by Willey (1979). It denotes the relative land area under sole crop required to give the same yield as obtained under mixed or an intercropping system at the same level of management.

$L E R=L E R a+L E R b=\frac{Y a b}{Y a a}+\frac{Y b a}{Y b b}$

Where,

Yaa $=$ Pure yield of main crop; Ybb = yield of intercrop; $\mathrm{Yab}$ and $\mathrm{Yba}=$ row proportion of main and intercrop respectively.

\section{Competitive Ratio (CR)}

Proposed by Willey et al. (1980). It is the ratio of individual LER of two component crops duly corrected for proportion in which they are grown. It is calculated separately for both the component crops, $a$ and $b$.

$\mathrm{A}_{\mathrm{ab}}=\frac{Y a b}{Y a a x Z a b} \times \frac{Y b a}{Y b b x Z b a}$

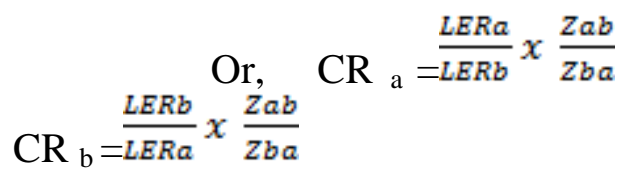
and

\section{Aggressivity}

It is proposed by Mc. Gilchrist (1965). It is a simple measure of how much the relative yield increase in component " $a$ " is obtained than that for component " $b$ ". " $A$ " can be calculated for both crops independently in a system. Greater the numerical value of A, bigger is the difference in competitive ability and bigger difference between actual and expected yield.

$$
\begin{aligned}
& \mathrm{A}_{\mathrm{ab}}=\frac{Y a b}{Y a a x Z a b}-\frac{Y b a}{Y a a x Z a b} \\
& \mathrm{~A}_{\mathrm{ba}}=\frac{Y b a}{Y b b x Z b a}-\frac{Y a b}{Y a a x Z a b}
\end{aligned}
$$

\section{Monetary advantage index (MAI)}

It was calculated by using the formula of (Ghosh, 2004)

MAI $=\frac{(\text { Value of intercrops })(\text { LER }-1)}{\text { LER }}$

\section{Results and Discussion}

Effect of intercropping on growth and yield attributes

Data in Table 1 shows the average growth and yield attributes of pea and mustard and their intercropping. The highest plant height of pea $(97.93 \mathrm{~cm})$ was recorded in 1:1 row proportion of Makhyatmubi with Indian mustard which was significantly higher than sole of Makhyatmubi $(78.8 \mathrm{~cm})$ and statistically at par with 2:1 row proportion $(85.40 \mathrm{~cm})$ and $3: 1$ row proportion of Makhyatmubi with Indian mustrad $(86.80 \mathrm{~cm})$. Significantly lowest plant height of Rachna was recorded when grown as sole $(50.27 \mathrm{~cm})$. The result of giving higher pea height in intercropping of Makhyatmubi with Indian mustard in 1:1 systems than its monoculture might be due to competition for light. Sole Indian mustard recorded taller plants $(105.60 \mathrm{~cm})$ than other intercrop treatments. This might be due to high plant density and competition for light. Similar results were reported by Singh and Yadav (1992) and Kumar et al. (2006). 
Number of pods per plant was significantly higher (8.73) when Rachna was intercropped with Indian mustard in $2 ; 1$ row ratio and it was closely followed by intercropping of Makhyatmubi with Indian mustard in 2:1 row ratio (8.27). Significantly lowest number of pods per plant was obtained from sole Makhyatmubi (5.82). It might be due to susceptible to lodging character of Makhyatmubi leading in poor development of pods.

Indian mustard produces significantly higher number of siliqua per plant when intercropped with Rachna in 1:1 row ratio (87.37). It might be due to advantage of additional nitrogen supplied by pea. In contrast the lowest (46.73) was recorded from the intercropping of Makhyatmubi with Indian mustard in 1:1 row ratio. It might be due to dominance of Indian mustard by Makhyatmubi thereby reducing the availability of sunlight for photosynthesis. Test weight of pea was significantly higher due to the seed size difference between Rachna and Makhyatmubi. Test weight of Indian mustard was found to be nonsignificant due to inherent character of the same variety.

\section{Effect of intercropping on yield}

Grain yield of pea and mustard were found to be highest in sole as compare to intercropping due to more plant population. Similar results were also reported by Singh and Singh (1998). Among the intercropping system significantly higher grain yield was recorded from Makhyatmubi with Indian mustard in 2:1 row ratio (1607.04 $\mathrm{kg} / \mathrm{ha})$ followed by Makhyatmubi with Indian mustard in 3:1 row ratio (1517.67). Among row proportions, the increase in the grain yield in 2:1 row proportion of Makhyatmubi with Indian mustard could be due to higher yield attributing parameters like pods per plant, test weight and number of seeds per pods because
Makhyatmubi being a susceptible crop to lodging needs proper support for higher number of pods and seed development which they got proper support from Indian mustard. The decrease in the yield in intercropping was due to less competition for sunlight, space, water and nutrients for sole crop as compared to intercropping treatments.

Indian mustard as sole crop recorded significantly higher seed $(1112.22 \mathrm{~kg} / \mathrm{ha})$ yield over intercropped Indian mustard. Similar results were also reported by Patel et al. (1991). The decrease in the yield in intercropping might be due to competition of crop plants for efficient utilization of natural resources and restricted growth of Indian mustard from initial stages to harvest resulting in yield competition for main and intercrops. Among the row proportions, 1:1 row proportion of Rachna with Indian mustard recorded significantly higher grain yield of Indian mustard due to higher yield attributes $v i z$, number of pods per plant, seeds per pod, and 1000-grain weight. Similar results were also reported by Tiwariet al. (1992).

\section{Effect of intercropping on indices}

Makhyatmubi equivalent yield was recorded highest $(1830 \mathrm{~kg} / \mathrm{ha})$ in 2:1 row proportion of Makhyatmubi with Indian mustard which was significantly higher than sole Makhyatmubi (1706 kg/ha). Lowest was found in sole Indian mustard (389 kg/ha). Highest makhyatmubi equivalent yield in 2:1 row proportion of Makhyatmubi with Indian mustard might be due to higher yield and higher market price of Makhyatmubi.

Intercropping of Pea with Indian mustard resulted in land equivalent ratio greater than 1 , except in sole crops indicating its advantage or biological efficiency and suitability of the practice in quantitative term. 
Table.1 Effect of pea based intercropping with Indian mustard on growth of pea and mustard (average for two years)

\begin{tabular}{|c|c|c|c|c|c|c|c|c|}
\hline \multirow[t]{2}{*}{ Treatment } & \multicolumn{2}{|c|}{ Plant height $(\mathrm{cm})$} & \multirow{2}{*}{$\begin{array}{l}\text { No. of } \\
\text { pods/ } \\
\text { plant }\end{array}$} & \multirow{2}{*}{$\begin{array}{c}\text { No. of } \\
\text { siliqua/ } \\
\text { plant }\end{array}$} & \multicolumn{2}{|c|}{ Test weight (g) } & \multicolumn{2}{|c|}{ Grain yield kg/ha) } \\
\hline & Pea & Mustard & & & Pea & Mustard & Pea & Mustard \\
\hline $\mathbf{T}_{1}$ & 50.27 & - & 10.60 & - & 228.67 & - & 1420.00 & - \\
\hline $\mathbf{T}_{2}$ & 78.80 & - & 5.87 & - & 292.67 & - & 1705.92 & - \\
\hline $\mathbf{T}_{\mathbf{3}}$ & - & 105.60 & - & 86.93 & - & 6.37 & - & 1112.22 \\
\hline $\mathbf{T}_{4}$ & 55.40 & 88.47 & 6.13 & 87.37 & 225.67 & 6.17 & 840.00 & 785.19 \\
\hline $\mathbf{T}_{5}$ & 97.93 & 102.07 & 7.73 & 46.73 & 301.67 & 6.23 & 1436.11 & 571.85 \\
\hline$T_{6}$ & 56.60 & 84.80 & 8.73 & 85.27 & 222.33 & 6.23 & 1090.37 & 718.52 \\
\hline $\mathbf{T}_{7}$ & 85.40 & 88.93 & 8.27 & 54.93 & 306.67 & 6.13 & 1607.04 & 637.04 \\
\hline $\mathbf{T}_{8}$ & 57.60 & 91.33 & 7.07 & 69.07 & 222.33 & 6.33 & 1287.40 & 645.93 \\
\hline $\mathbf{T}_{9}$ & 86.80 & 84.73 & 7.47 & 50.07 & 295.00 & 6.23 & 1517.67 & 533.70 \\
\hline S.Ed $( \pm)$ & 2.86 & 5.81 & 0.71 & 7.12 & 3.08 & 0.27 & 155.46 & 100.70 \\
\hline $\mathrm{CD}(\mathrm{P}=0.05)$ & 14.97 & 12.66 & 1.52 & 15.50 & 16.17 & NS & 333.45 & 219.33 \\
\hline
\end{tabular}

$T_{1}$-Sole Rachna; $T_{2}$-Sole Makhyatmubi; $T_{3}$-Sole Indian mustard; $T_{4}$-Rachna+Indian mustard (1:1); $T_{5^{-}}$ Makhyatmubi+Indian mustard (1:1); $\mathbf{T}_{6}$-Rachna+Indian mustard (2:1); $\mathrm{T}_{7}$-Makhyatmubi+Indian mustard (2:1); T $_{8}$-Rachna+Indian mustard (3:1); $\mathbf{T}_{9}$-Makhyatmubi+Indian mustard (3:1)

\begin{tabular}{|l|c|c|c|c|c|c|c|}
\hline \multicolumn{7}{|l|}{ Table.2 Effect of pea based intercropping with Indian mustard on competition indices(average for } \\
two years)
\end{tabular}


The obvious reason for yield advantage in intercropping system was due to the fact that the component crops have combined effect of better utilization of growth resources than sole cropping of companion crops and converting them more efficiently resulting in higher yields per unit area than that produced by the sole crops. Similar results were reported by Singh and Singh (1998). Competitive ratio was observed highest (1.66) in 1:1 row proportion of makhyatmubi with indian mustard and lowest (0.53) was found in 3:1 row proportion of Rachna with Indian mustard indicating more efficient combinations than other intercropping systems (Table 2). This might be due to the companion crop pea appeared less competitive than Indian mustard, giving lower value of competitive ratio.

Relative crowding coefficient of pea was recorded highest (8.23) in 2:1 row proportion of Makhyatmubi with Indian mustard and lowest (1.74) in 1:1 row proportion of Rachna with Indian mustard. For Indian mustard relative crowding coefficient was recorded highest (4.29) in 3:1 row proportion of Rachna with Indian mustard and lowest (1.09) in 1:1 row proportion of Makhyatmubi with Indian mustard. Similar results were also reported by Tuti et al., (2012). Among intercroppings, Makhyatmubi + Indian mustard in 2:1 row ratio had a higher monetary advantage index (Rs 60883). The higher the MAI value the more profitable is the cropping system (Ghosh, 2004).

From the present investigation it can be concluded that intercropping of Makhyatmubi with Indian mustard in 2:1 row ratio was found to be beneficial.

\section{Acknowledgement}

Authors are thankful to the Dean, College of Agriculture, Central Agricultural University,
Imphal for providing both financial as well as technical support to carry out the above M.Sc. thesis research.

\section{References}

Adeniyi, O.R. 2011. Economic aspects of intercropping systems of vegetables (okra, tomato and cowpea). African Journal of Plant Science.5:648-655.

Fustec, J., Lesuffleur, F.,Mahieu, S. and Cliquet, J.B. 2010.Nitrogen rhizodeposition of legumes. A review. Agronomy for Sustainable Development.30:57-66.

Ghosh, P.K. 2004. Growth, yield, competition and economics of groundnut/cereal fodder intercropping systems in the semi-arid tropics of India. Field Crops Research.88:227-237.

Kumar, R., Ali, M., Arya, R.L. and Mishra, J.P. 2006.Enhancing productivity and profitability of Chickpea (Cicerarietinum) + Indian mustard (Brassica juncea) intercropping system.Indian Journal of Agronomy.51(2): 27-30.

McGilchrist, C.A. 1965. Analysis of competition experiments.Biometrics.21:975-985.

Patel, B.R., Dilip, S. and Gupta, M. L. 1991. Effect of irrigation and intercropping on gram and mustard. Indian Journal of Agronomy. 36(2): 283-284.

Singh, B.D. and Singh, B.P. 1998. Effect of weed management practices and phosphorus levels on weed infestation, nodulation and yield of chickpea + mustard intercropping system. Indian Journal of Weed Science.30: 124-128.

Singh, D.K. and Yadav, D.S. 1992. Production potential and economics of chickpea (Cicer arietinum) based intercropping systems under rainfed condition. Indian Journal of 
Agronomy, 37(3): 424-429.

Tiwari, K.P., Tomar, R.K.S., Mishra, G.L. and Raghu, J.S. 1992. Intercropping of mustard with gram and lentil. Journal of Oilseeds Research. 9(2): 248-252.

Tsubo, M., Walker, S. and Mukhala, E. 2001. Comparisons of radiation use efficiency of mono-/inter-cropping systems with different row orientations. Field Crops Research. 71:17-29.

Tuti, M.D., Mahanta, D., Mina, B.L., Bhattacharya, R., Bisht, J.K., Bhatt, J.C. 2012. Performance of lentil (Lens culinaris) and toric (Brassica compestris) intercropping with wheat (Triticum aestivum) under rainfed conditions of north-west Himalaya. Indian Journal of Agricultural Science. 82(10): 841-4.
Verma, S.P. and Modgal, S.C. 1983. Production potential and economics of fertilizer application as resource constraint in maize-wheat crop sequence. Himachal Pradesh Journal of Agricultural Research. 9: 89-92.

Willey, R.W. 1979. Intercropping-its importance and research need. Competition and yield advantage. Field Crops Abstract. 32(1): 1-10.

Willey, R.W., Natarajan, M., Reddy, M.S., Rao, M.R., Nambiar, P.T.C., Kammainan, J. and Bhatanagar, V.S. 1980.Intercropping studies with annual crops. In Better Crops for Food. CIBA Foundation Symposium, Vol. 512, pp. 83-97. (Ed J. C. Homeless). London: Pitman Books Ltd.

\section{How to cite this article:}

Mary Chongtham, K. Nandini Devi, Nurina Shahni, Herojit Singh Athokpam, N. Gopimohan Singh, Kangujam Bokado and Dorendro Singh, A. 2018. Evaluation of Pea (Pisum sativum L.) and Indian Mustard (Brassica juncea L.) Intercropping System on Growth, Yield and Competition Indices. Int.J.Curr.Microbiol.App.Sci. 7(07): 2502-2508.

doi: https://doi.org/10.20546/ijcmas.2018.707.293 